\title{
Celiac crisis in children in Serbia
}

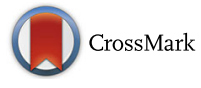

\author{
Nedeljko Radlovic ${ }^{1,2,3^{*}}$, Zoran Lekovic ${ }^{1,2}$, Vladimir Radlovic ${ }^{2}$, Dusica Simic ${ }^{1,2}$, Biljana Vuletic $^{4}$, Sinisa Ducic ${ }^{1,2}$ \\ and Zorica Stojsic ${ }^{1,5}$
}

\begin{abstract}
Background: To assess the prevalence and risk factors of celiac crisis (CC) in children with classical celiac disease (CD).

Methods: This retrospective study comprised 367 children with classical CD diagnosed from 1994 to 2015. The diagnosis of CD was based on the revised ESPGHAN criteria and CC on acute worsening and rapid progression of chronic diarrhea and vomiting followed by severe dehydration, multiple metabolic derangements and a marked decrease of body weight.

Results: Celiac crisis was confirmed in six (1.63 \%) children, five in the first and one in the second year of life. In three patients CC was precipitated by rotavirus and in one by Salmonella enteritidis infection, while in the remaining two, except for a too long-standing disease and severe malnutrition, no additional causes of CC were found.

Conclusion: Celiac crisis in Serbia is still-present in children exclusively below the second year of life as a spontaneous or intestinal infection precipitated complication of previously unrecognized CD.
\end{abstract}

Keywords: Celiac crisis, Children, Developing country

\section{Background}

Celiac crisis $(\mathrm{CC})$ is an urgent and potentially fatal complication of celiac disease (CD) [1-4]. It is most often seen in early childhood, but may also occur later, including adult and elderly age group [1,5-9]. It is clinically manifested by deterioration and rapid progression of serious digestive dysfunction followed by profuse watery diarrhea, severe dehydration and profound metabolic and nutritional abnormalities $[1-5,7,10]$. It is usually seen as a complication of previously unrecognized $\mathrm{CD}$, and rarely as a consequence of non-compliance with the recommended gluten-free diet $[3-5,7]$.

We are presenting our experience related to the frequency of CC in children with classical CD in Serbia and the risk factors for its development. Additionally, we are reporting the therapy of this serious complication of $\mathrm{CD}$.

\section{Methods}

The study is retrospective and includes 367 children (240 female; with age range of 7 months to 15.25 years,

\footnotetext{
* Correspondence: n.radlovic@beotel.net

${ }^{1}$ Faculty of Medicine, University of Belgrade, Dr Subotica 9, Belgrade 11000, Serbia

${ }^{2}$ University Children's Hospital, Tirsova 10, Belgrade 11000, Serbia

Full list of author information is available at the end of the article
}

mean $1.69 \pm 1.48$ years) with classical CD confirmed in two of the five reference centers in Serbia during the period from January 1994 to December 2015. The study protocol was approved by the local ethics committee. The classical type of CD implied chronic diarrhea, poor appetite and undernutrition [1, 2]. Most patients, (296, $80.65 \%)$ were below the age of 2 years, of whom 129 were diagnosed in the first and 167 in the second year of life. In 346 patients the diagnosis of $\mathrm{CD}$ was based on the revised criteria of the European Society for Pediatric Gastroenterology, Hepatology and Nutrition (ESPGHAN) from 1989 [11], i.e. on the characteristic histopathological findings of small bowel mucosa and clinical recovery of patients on gluten-free diet, as well as on the confirmed clinical and/or histopathological relapse of the disease during gluten challenge at the age of 5-7 years in those diagnosed before completed second year of life. In 21 of them (13 female, age range of 10 months to 4.50 years, mean $1.82 \pm 0.99$ years) the diagnosis was based on the new ESPGHAN guidelines published in 2012 according to which there is no need for small intestinal biopsy in patients with signs or symptoms corresponding to CD, with IgA anti-tissue transglutaminase (anti-TTG) titers levels 10 times above the upper limit of normal, positive anti-endomysial antibody, presence of HLA-DQ2 and/or 
HLA-DQ8 and full clinical recovery on gluten-free diet [12]. All of them were diagnosed between 2012 and 2015.

Celiac crisis diagnosis was based on acute worsening and rapid progression of chronic diarrhea followed by severe dehydration, metabolic acidosis, hypotension, renal dysfunction, abdominal distension, hypoproteinemic edema and a marked decrease of body weight $[1-3,10]$.

Beside the history of the onset and course of the disease, a complete physical examination and standard laboratory investigations, all patients with $\mathrm{CC}$ underwent stool examination for bacterial infection, ova and parasites, latex agglutination test on rotavirus and adenovirus, duodenal fluid for Giardia lamblia and five serum testing for anti-TTG antibodies. In all six patients HLA genotyping was done as described in Stankovic et al. [13].

Initial therapy comprised of intravenous rehydration, correction of acidosis and hypoalbuminemia, interruption of oral feeding for the first $8-12 \mathrm{~h}$, and in three cases with enormous abdominal distention a 1-day placement of a rubber tube in the rectum. To achieve full recovery of the patients, in addition to the strict gluten-free diet, supportive parenteral nutrition for 10 to 15-days and lactose-free diet for 2 to 3-weeks were necessary. Due to persistent secretory diarrhea and perpetual anorexia requiring a continual intravenous fluid substitution, in two cases, both without clinical and laboratory indications of infection, a 5-day oral prednisone therapy in the dose of $2 \mathrm{mg} / \mathrm{kg}$ daily was also necessary.

After 2 weeks of treatment, small intestinal biopsy was performed and histological findings were classified according to the modified Marsh criteria [14].

\section{Results}

Celiac crisis was detected in six (1.63\%) children (4 female; aged 8 to 15 months, mean $10.50 \pm 2.59$ months), all at the time of initial presentation of classical CD. Five patients were in the first and one in the second year of life, thus the prevalence of $\mathrm{CC}$ for this age group was $2.03 \%$, i.e. $3.88 \%$ for the first and $0.60 \%$ for the second one. Year of hospitalization and basic clinical data of patients with $\mathrm{CC}$ are presented on Table 1. Laboratory findings on admission showed mild metabolic acidosis
( $\mathrm{pH}$ capillary blood 7.21-7.26; $7.23 \pm 0.02$ ), low serum levels of albumin $(18-24 \quad(21.50 \pm 2.81 \mathrm{~g} / \mathrm{L})$, sodium ((123-129; $126 \pm 2.90 \mathrm{mmol} / \mathrm{L})$, potassium $(2.1-2.9 ; 2.45 \pm$ $0.339 \mathrm{mmol} / \mathrm{L})$, calcium $(1.02-1.98 ; 1.59 \pm 0.42 \mathrm{mmol} / \mathrm{L})$, magnesium (0.61-0.68; $0.65 \pm 0.026 \mathrm{mmol} / \mathrm{L})$ and phosphorus (0.62-0.79 $(0.69 \pm 0.07 \mathrm{mmol} / \mathrm{L})$, high serum creatinine $(96-133 ; 107.33 \pm 13.53 \mu \mathrm{mol} / \mathrm{L})$ and anemia (Hb 71-98; $85.17 \pm 9.67 \mathrm{~g} / \mathrm{L})$.

In four patients $\mathrm{CC}$ was probably precipitated by intestinal infection caused by rotavirus in three and by Salmonella enteritidis in one, while in the remaining two, except for a too long-standing disease and severe malnutrition, no additional causes of $\mathrm{CC}$ were found.

In all six cases the stereomicroscopic and histological examination of the small intestinal mucosa showed a total villous atrophy (Marsh IIIc) (Fig. 1) and were homozigous carriers of HLA-DQ2.5 haplotype characterised by HLADRB1*03, HLA-DQA1*05 and HLA-DQB1*02 alleles present on a single (in cis configuration). Additionally, all five tested were positive to IgA anti-TTG antibodies (58.6 to $88 \mathrm{U} / \mathrm{ml})$.

\section{Discussion}

Owing to advancement in knowledge and diagnostics of $\mathrm{CD}, \mathrm{CC}$ is rare today, even in the developing countries $[3,5]$. However, there is no any publication either in pediatric or adult medicine precisely tackling the issue of its current incidence [7]. Besides, there are no papers, review or original, which systematically consider the basis of the occurrence and possibilities of CC treatment at this point of time.

Our analysis originating from Serbia, which is a developing country, indicates that $\mathrm{CC}$ in children is rare today, and that it is seen only by the end of the first and the beginning of the second year of life as a spontaneous or precipitated complication of unrecognized on time and neglected $\mathrm{CD}$. In our three patients the precipitated factor of $\mathrm{CC}$ was probably rotavirus gastroenteritis and in one Salmonella enteritidis, while in the remaining two, except for a too long-standing disease and severe malnutrition, no additional causes of $\mathrm{CC}$ were determined. The significance of intestinal infection as one of

Table 1 Basic data for children with CC

\begin{tabular}{|c|c|c|c|c|c|c|c|}
\hline Case & $\begin{array}{l}\text { Year of } \\
\text { hospitalization }\end{array}$ & $\begin{array}{l}\text { Duration of breast } \\
\text { feeding (mths.) }\end{array}$ & $\begin{array}{l}\text { Age at gluten } \\
\text { introduction (mths.) }\end{array}$ & $\begin{array}{l}\text { Age at onset of CD } \\
\text { symptoms (mths.) }\end{array}$ & $\begin{array}{l}\text { Age at diagnosis } \\
\text { (mths.) }\end{array}$ & $\begin{array}{l}\text { Deficit of BW on } \\
\text { admission (\%) }\end{array}$ & Edema \\
\hline 1 & 1999 & 2 & 3.5 & 12.5 & 15 & 22.5 & + \\
\hline 2 & 2004 & 1.5 & 3 & 8 & 10 & 32 & + \\
\hline 3 & 2004 & 0.3 & 3 & 6 & 8 & 33 & + \\
\hline 4 & 2005 & 1 & 3.5 & 7.5 & 9 & 28 & + \\
\hline 5 & 2009 & 0.5 & 3 & 7.5 & 9 & 28 & + \\
\hline 6 & 2010 & 0.25 & 4 & 11 & 12 & 24 & + \\
\hline
\end{tabular}




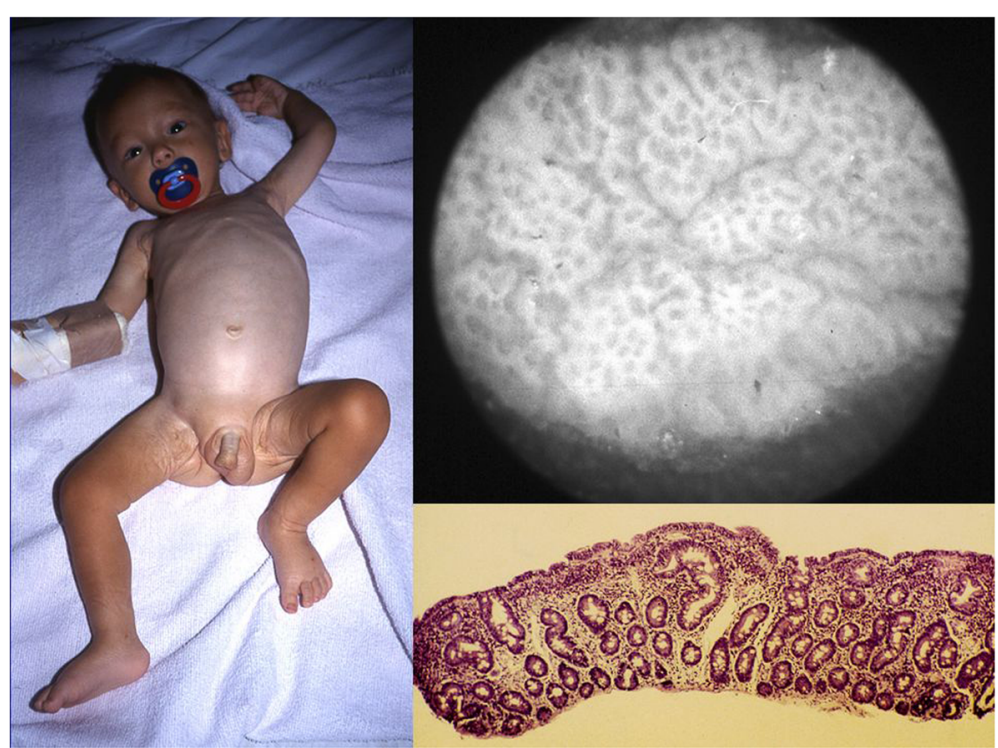

Fig. 1 Male patient in initial phase of recovery and it's stereomicroscopic and histological appearance of the small intestinal mucosa

the precipitating factors of $\mathrm{CC}$ in patients with active $\mathrm{CD}$ and marked malnutrition is well known and is reflected, not only by a rapid deterioration of already disordered digestive functions, but also by severe anorexia and fever induced hypermetabolic condition. In three of our patients this is particularly marked in intercurrent rotavirus gastroenteritis, where both autoimmune and infective mechanisms contribute to the proximal small bowel segment mucosa damage, i.e. in the segment that plays the central role in food digestion and absorption [15]. It is the fact that intestinal infections are pointed out as a precipitating factor of $\mathrm{CC}$, however, to our knowledge the available literature does not mention rotavirus gastroenteritis specifically. Additionally, all six children were homozigous carriers of HLA-DQ2.5 haplotype as a high-risk for early expression of $\mathrm{CD}$ and possibility of $\mathrm{CC}$ as its complication at this age $[16,17]$.

The first therapeutic procedures were aimed at vital care and stabilization of the patients' condition, while for their definite recovery, beside the standard measures, in two patients a short-term prednisone therapy was also necessary. According to other authors' experience, although risky, steroids used to treat resistant forms of CC have proved successful $[5,6,18,19]$.

The explanation for the fact that CC in our two institutions registered in the middle of the observed period, i.e. from 1999 to 2010, probably lies in the fall of economic standard in the country in this context and the level of healthcare. However, in the last 5 years we did not have any patient with $\mathrm{CC}$, which can be explained by a more stable situation in the country in general, and in this context, and improvement of $\mathrm{CD}$ diagnosis.

\section{Conclusion}

Celiac crisis in Serbia is still-present in children and occurs exclusively by the end of the first or the beginning of the second year of life as a spontaneous or intestinal infection precipitated complication of classical $\mathrm{CD}$ unrecognized on time.

Written informed consent was obtained from the patient's legal guardian(s) for publication of this case report and any accompanying images. A copy of the written consent is available for review by the Editor-in-Chief of this journal.

\section{Competing interests}

The authors declare that they have no competing interests.

\section{Authors' contributions}

NR key role in study concept and design and drafting of the manuscript. ZL study design and coordination and drafting of the manuscript. VR drafting of the manuscript. DS, BV and SD helped in drafting of the manuscript. ZS Interpretation of the pathohistological findings of small intestinal mucosa. All authors read and approved the final manuscript.

\section{Author details}

${ }^{1}$ Faculty of Medicine, University of Belgrade, Dr Subotica 9, Belgrade 11000, Serbia. ${ }^{2}$ University Children's Hospital, Tirsova 10, Belgrade 11000, Serbia. ${ }^{3}$ Academy of Medical Sciences of the Serbian Medical Society, Dzordza Vasingtona 19, Belgrade 11000, Serbia. ${ }^{4}$ Pediatric Clinic, Clinical Centre, Zmaj Jovina 30, Kragujevac 34000, Serbia. ${ }^{5}$ Institute of Pathology, Faculty of Medicine, University of Belgrade, Dr Subotica 1, Belgrade 11000, Serbia.

Received: 27 December 2015 Accepted: 23 February 2016

Published online: 01 March 2016

\section{References}

1. Weir DC, Kelly C. Celiac disease. In: Duggan C, Watkins JB, Walker AW, editors. Nutrition in Pediatrics. 4th ed. Hamilton: BC Decker Inc; 2008. p. 561-8.

2. Fasano A, Catassi C. Clinical practice. Celiac disease. N Engl J Med. 2012; 367(25):2419-26.

3. Walia A, Thapa BR. Celiac crisis. Indian Pediatr. 2005;42:1169. 
4. Dogan M, Yuca SA, Acikgöz M, Doğan SZ, Kaya A, Cesur Y. Celiac disease with celiac crisis. Eur J Gen Med. 2010;7(2):213-5.

5. Baranwal AK, Singhi SC, Thapa BR, Kakkar N. Celiac crisis. Indian J Pediatr. 2003;70(5):433-5.

6. Mones RL, Atienza KV, Youssef NN, Verga B, Mercer GO, Rosh JR. Celiac crisis in the modern era. J Pediatr Gastroenterol Nutr. 2007:45(4):480-3.

7. Jamma S, Rubio-Tapia A, Kelly CP, Murray J, Najarian R, Sheth S, et al. Celiac crisis is a rare but serious complication of celiac disease in adults. Clin Gastroenterol Hepatol. 2010;8(7):587-90.

8. Mrad RA, Ghaddara HA, Green PH, El-Majzoub N, Barada KA. Celiac Crisis in a 64-year-old woman: An unusual cause of severe diarrhea, acidosis, and malabsorption. ACG Case Rep J. 2015;2(2):95-7.

9. Yilmaz B, Aksoy EK, Kahraman R, Yaprak M, Sıkgenc M, Dayan R, et al. Atypical presentation of celiac disease in an elderly adult: Celiac crisis. J Am Geriatr Soc. 2015;63(8):1712-4.

10. Gupta S, Kapoor K. Steroids in celiac crisis: doubtful role! Indian Pediatr. 2014;51(9):756-7.

11. Walker-Smith JA, Guandalini S, Schmitz J, Shmerling DH, Visakorpi JK. Revised criteria for diagnosis of coeliac disease. Report to working group of European Society of Paediatric Gastroenterology and Nutrition. Arch Dis Child. 1990;65(8):909-11.

12. Husby S, Koletzko S, Korponay-Szabó IR, Mearin ML, Phillips A, Shamir R, et al. European Society for Pediatric Gastroenterology, Hepatology, and Nutrition guidelines for the diagnosis of coeliac disease. J Pediatr Gastroenterol Nutr. 2012;54(1):136-60.

13. Stanković B, Radlović N, Leković Z, Ristić D, Radlović V, Nikčević G, et al. HLA genotyping in pediatric celiac disease patients. Bosn J Basic Med Sci. 2014;14(3):171-6.

14. Oberhuber G, Granditsch G, Vogelsang H. The histopathology of coeliac disease: time for a standardized report scheme for pathologists. Eur J Gastroenterol Hepatol. 1999;11(10):1185-94.

15. Huppertz H-I, Salman N, Giaquinto C. Risk factor for severe rotavirus gastroenteritis. Pediatr Infect Dis J. 2008;27:S11-9.

16. Lionetti $E$, Castellaneta S, Francavilla R, Pulvirenti A, Tonutti E, Amarri S, et al. Introduction of gluten, HLA status, and the risk of celiac disease in children. N Engl J Med. 2014;371(14):1295-303.

17. Liu E, Lee HS, Aronsson CA, Hagopian WA, Koletzko S, Rewers MJ, et al. Risk of pediatric celiac disease according to HLA haplotype and country. N Engl J Med. 2014;371(1):42-9.

18. Lloyd-Still JD, Grand RJ, Khaw KT, Schwachman H. The use of corticosteroids in celiac crisis. J Pediatr. 1972:81:1074-81.

19. Chaurasiya OS, Gupta S, Sadawarti B, Jaiswal C. Case report: Celiac disease with celiac crisis. Curr Pediatr Res. 2015;19(1):51-3.

\section{Submit your next manuscript to BioMed Central and we will help you at every step:}

- We accept pre-submission inquiries

- Our selector tool helps you to find the most relevant journal

- We provide round the clock customer support

- Convenient online submission

- Thorough peer review

- Inclusion in PubMed and all major indexing services

- Maximum visibility for your research

Submit your manuscript at www.biomedcentral.com/submit

) Biomed Central 